\title{
First record of a brown widow spider Latrodectus geometricus Koch, 1841 (Araneae, Theridiidae) feeding scorpion (Scorpiones, Bothriuridae) in a Brazilian Atlantic forest
}

\author{
Lira, AFA. ${ }^{a *}$ and Costa, $A A .^{a}$ \\ aPrograma de Pós-graduação em Biologia Animal, Departamento de Zoologia, Universidade Federal de \\ Pernambuco - UFPE, Rua Prof. Moraes Rego, s/n, Cidade Universitária, CEP 50670-420, Recife, PE, Brazil \\ *e-mail: andref.lira@gmail.com
}

Received: October 10, 2013 - Accepted: March 19, 2014

(With 1 figure)

\begin{abstract}
Scorpions are generalist predators, capturing a great variety of arthropods including even small vertebrates (Polis, 1990), however, they are also subject to predation, especially by vertebrates such as amphibians, reptiles, birds and mammals (Polis et al., 1981; McCormick and Polis, 1990). Regarding the invertebrates, there are reports of predation by coleopterans, chilopods, solpugids, others scorpions and spiders (Cloudsley-Thompson, 1960; Williams, 1966; Cloudsley-Thompson, 1977; Punzo, 1998; McCormick and Polis, 1990; Melic, 2000). There is no record for this phenomenon in the Brazilian Atlantic Forest. To increase knowledge about the natural history these arachnids, this paper reports the first case of scorpion predation by spider for this biome. The observation was reported during field work in Reserva Particular de Patrimônio Natural Nossa Senhora do Oiteiro de Maracaípe

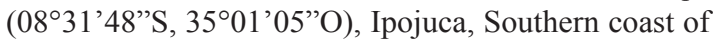
Pernambuco state, Brazil. The reserve area totals 76.2 ha, of these, 29.7 ha occupied by Atlantic forest (22.7\%) classified by restinga and 46.5 ha occupied by mangroves. On 15-I-2013 at about 9:00 pm, following the nocturnal collection of a scorpion sample (active search), the second author (Costa, A.) noted on a scorpion (Bothriurus sp.) caught in the web of Latrodectus geometricus Koch, 1841 on a small bush approximately $30 \mathrm{~cm}$ above the ground (Figure 1). The scorpion found himself paralyzed, with the spider feeding its fluids. Probably the scorpion was captured while walking through the litter as this type of spider prey capture touching sues capture vertical wires
\end{abstract}

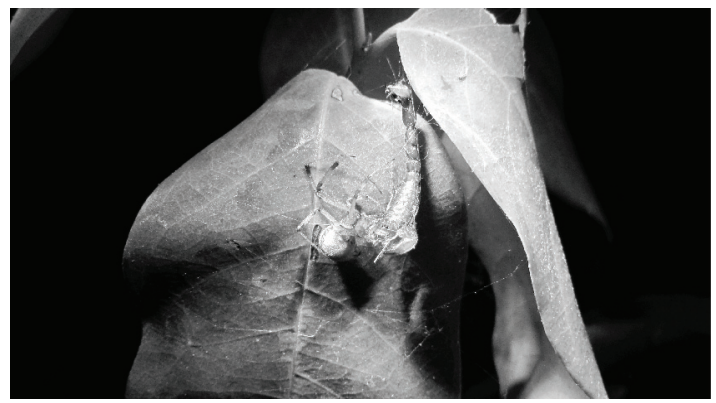

Figure 1. The brown widow spider Latrodectus geometricus feeding a scorpion Bothriurus sp. down and quickly injecting its paralyzing venom. Both, the spider and the scorpion were deposited in Arachnological Collection of Universidade Federal de Pernambuco, Recife, Brazil. The present case of predation may be considered as occasional. Latrodectus geometricus is not a regular predator of scorpions, but a generalist hunter that feeds on large diversity of prey like others Latrodectus species (Melic, 2000).

\section{Acknowledgements}

We are very grateful to the Wellington Buarque for the permission to use the area to collect samples. We are also very grateful to CAPES for the scholarship to the first author.

\section{References}

CLOUDSLEY-THOMPSON, JL., 1960. Notes on Arachnida, 35 - A scorpion eaten by a beetle. Entomologist's Monthly Magazine, vol. 95 , p. 223.

CLOUDSLEY-THOMPSON, JL., 1977. Adaptational biology of Solifugae (Solpugida). Bulletin (British Arachnological Society), vol. 4 , no. 2 , p. 61-71.

MCCORMICK, SJ. and POLIS, GA., 1990. Prey, predators, and parasites. In: POLIS, GA. (Ed.). The biology of scorpions. Stanford: Stanford Univ. Press. p. 294-320.

MELIC, A., 2000. El género Latrodectus Walckenaer, 1805 en la peninsula Ibérica (Araneae: Theridiidae). Revista Ibérica de Aracnologia, vol. 1, p. 13-30.

POLIS, GA., 1990. The Biology of Scorpions. Stanford: Stanford University Press. 587 p.

POLIS, GA., SISSOM, WD. and MCCORMICK, SJ., 1981. Predators of scorpions: field data and a review. Journal of Arid Environments, vol. 4, p. 309-326.

PUNZO, F., 1998. The biology of camel spiders (Arachnida, Solifugae). Boston: Kluwer Academic Pub. 312 p. http://dx.doi. org/10.1007/978-1-4615-5727-2.

WILLIAMS, SC., 1966. Burrowing habitat of the scorpion Anuroctonus phaeodactylus (Wood) (Scorpionida: Vaejovidae). Proceedings of the California Academy of Sciences, vol. 34, no. 4, p. 419-428. 